\title{
Isolation, Identification and Medium Optimization for Tyrosinase Production by a Newly Isolated Bacillus subtilis NA2 Strain
}

\author{
Elsayed Ahmed Elsayed ${ }^{1,3}$, Enas Nabil Danial2,3* \\ ${ }^{1}$ Bioproducts Research Chair, Zoology Department, Faculty of Science, King Saud University, 11451 Riyadh, Kingdom of Saudi Arabia. \\ ${ }^{2}$ Applied Biochemistry Department, Faculty of Science, University of Jeddah, Jeddah, Saudi Arabia. \\ ${ }^{3}$ Chemistry of Natural and Microbial Products Department, National Research Centre, Dokki, Cairo, Egypt.
}

\section{ARTICLE INFO \\ Article history: \\ Received on: 05/05/2018 \\ Accepted on: 10/07/2018 \\ Available online: 30/09/2018}

\section{Key words:}

Isolation, Identification,

Bacillus, Tyrosinase,

coefficient.
Production, Yield

\begin{tabular}{l}
\hline ABSTRACT \\
Tyrosinase (EC 1.14.18.1, monophenol, O-diphenol: oxygen oxidoreductase) is a copper-metallo-bifunctional enzyme, \\
which catalyzes the O-hydroxylation and oxidation of monophenols to quinones. Tyrosinase plays an important role \\
in the immune defense mechanisms of many prokaryotic and eukaryotic organisms. It also finds many applications in \\
antioxidants and therapeutic fields. In the present work, a newly isolated tyrosinase-producing strain (Bacillus subtilis \\
$\mathrm{NA} 2)$ was identified using $16 \mathrm{~S} \mathrm{rDNA}$ and $\mathrm{BLAST}$ analysis. The primary cultivation medium produced tyrosinase at \\
$416.67 \mathrm{U} / \mathrm{min} / \mathrm{mL}$ with a yield coefficient $\left(Y_{P / X}\right)$ of $111.75 \times 10^{3} \mathrm{U} / \mathrm{g}$ cells. Furthermore, the cultivation medium for \\
the production of tyrosinase was optimized. The final optimized cultivation medium composed of $(\mathrm{g} / \mathrm{L})$ : sucrose, 10 ; \\
$\mathrm{KNO}_{3}, 10 ; \mathrm{K}_{2} \mathrm{HPO}_{4}, 0.5 ; \mathrm{MgSO}_{4} .7 \mathrm{H}_{2} \mathrm{O}, 0.25$; tyrosine, 10 and the initial optimized pH of the cultivation medium was \\
8.5. It has been shown, that the final optimized medium with the optimized pH resulted in an increase of about $39 \%$ \\
in tyrosinase production from the initial un-optimized conditions. The new tyrosinase producing strain was identified \\
and its volumetric production was significantly increased after the successful optimization of the production medium.
\end{tabular}

\section{INTRODUCTION}

Tyrosinase (EC 1.14.18.1, monophenol, O-diphenol: oxygen oxidoreductase) is a copper-metalloprotein that is ubiquitously dispensed in nature. Tyrosinase is a bifunctional enzyme and a monooxygenase that catalyzes the $O$-hydroxylation and subsequent oxidation of monophenols, $O$-phenols, to quinones (Claus and Decker 2006). Tyrosinase plays an important role in wound healing and the primary immune response of plant life, sponges and many invertebrate (Danial et al., 2018; Decker and Tuczek 2000). In human, tyrosinase produces melanin species as a defense against the harmful effects of UV light (Kumar et al., 2011). In plants, it is necessary to synthesize phenolic polymers such as tannins, lignin, and flavonoids. In fungi, this enzyme has crucial importance in virulence and survives reproductive organ differentiation, protection of tissue after infection and spore

\section{${ }^{*}$ Corresponding Author}

Enas Nabil Danial, Applied Biochemistry Department, Faculty of

Science, University of Jeddah, Jeddah, Saudi Arabia.

E-mail:enmahdi@kau.edu.sa formation (Seo et al., 2003). In bacteria, tyrosinase enzyme is the key enzyme in initiating the melanin biosynthesis pathway and has vital roles in their protection. Tyrosinase has been extracted, isolated and purified from various sources such as animals, plants, insects, and microorganisms (Saratale et al., 2011; Xu et al., 2012). biotechnological applications for both small phenolic compounds and protein-associated phenolic groups. One of their applications is in the bioremediation of polluted soil and wastewater containing phenolic compounds (Marino et al., 2011). The phenolic molecules are changed by the enzyme to quinones, which are auto-oxidized to become insoluble polymeric compounds and precipitate in water. The enzyme has a significant role in the medical sector, for example, the production of L-DOPA, a favored medication for the treatment of Parkinson's disease (Franciscon et al., 2012). The enzyme is also used in the production of hydroxytyrosol as an estrogenic intermediate (Zhang et al., 2007), food additives (Decker and Tuczek 2000), and melanin production for therapeutic applications (Pandey et al., 1989).

Tyrosinase is found in prokaryotic microorganisms, as well as eukaryotic mammals, invertebrates, and plants. Various
Due to oxidative stress properties, tyrosinase has 
organisms have been used for the production of tyrosinase enzymes on a commercial scale, i.e. bacteria, fungi, and mushrooms, etc. Phytase genes from these organisms were later expressed in Escherichia coli and the enzyme production was studied in both batch and fed-batch cultivations (Allouche et al., 2004). Streptomyces species isolated from soil were also used for the in vitro production of the extracellular tyrosinase (Rao et al., 2013).

Until recently, tyrosinase was produced at a concentration of about $1 \mathrm{~g} / \mathrm{L}$ through the cultivation of the filamentous Trichoderma reesei (Caf et al., 2012). Moreover, immobilized tyrosinase enzymes were used for the production of L-DOPA (Shuster and Fishman, 2009). The trade production and extraction of tyrosinase are reported from Agaricus bisporus mushroom. Extensive research has been carried out on the production and immobilization of tyrosinase from A. bisporus. Recently, Dalfard et al. (2006) isolated and characterized a melanogenic soil bacterium capable of producing tyrosinase as well as laccase enzymes, and reported a tyrosinase activity of $2.38 \mathrm{U} / \mathrm{mL}$.

The studies reported here accomplished aimed at (i) isolation, identification of tyrosinase-producing Bacillus sp., and (ii) optimization of the culture conditions (nutritional and physical parameters) for increased production of tyrosinase using the isolated Bacillus sp.

\section{MATERIALS AND METHODS}

\section{Chemicals and reagents}

All chemicals/reagents used throughout the work were of high-quality analytical grade and were purchased from SigmaAldrich Chemical Company, St. Louis, MO, USA.

\section{Samples collection}

One gram of soil (Soil from the potato-planted field, Mansoura Governorate, Egypt) was transferred to $9 \mathrm{~mL}$ sterile saline solution (under aseptic conditions), and the tubes were shaken well to get a dilution of $10^{-1}$. Several serial dilutions were then made to obtain a proper dilution of $10^{-3}$.

An aliquot of $0.1 \mathrm{ml}$ of each dilution was transferred over agar plates containing (yeast extract $0.15 \%$, tryptone $0.15 \%$, $\mathrm{NaCl} 0.5 \%$ and L-Tyrosine $0.1 \%$ ) and the brown-black colony forming strains as prospective strains were selected to have tyrosinase enzyme. The best of the strains, in terms of brownblack color development due to melanin production, was selected and subjected to enzyme production (Shuster and Fishman, 2009). The plates were incubated at $35^{\circ} \mathrm{C}$ for $24 \mathrm{~h}$.

\section{Isolation of the tyrosinase producing strain}

Among 30 different bacterial strains isolated a potent strain which gave a high yield of tyrosinase was chosen for further study. The bacterial strains were routinely grown on nutrient agar medium (Dalfard et al., 2006) at $35^{\circ} \mathrm{C}$ for 3 days then preserved at $-80^{\circ} \mathrm{C}$ in glycerol.

\section{Identification of tyrosinase producing bacteria}

\section{DNA isolation and PCR amplification}

An overnight culture of the promising bacteria grown at $35^{\circ} \mathrm{C}$ was used for the preparation of genomic DNA. The DNA was isolated using Promega kit for preparation of genomic DNA according to the manufacturer's instructions. PCR amplification of $16 \mathrm{~S}$ rDNA region was carried out according to Sambrook et al. (1989). The 16S rDNA was amplified by polymerase chain reaction (PCR) using primers designed to amplify $1500 \mathrm{bp}$ fragment of the $16 \mathrm{~S}$ rDNA region. The domain bacteria-specific primer $27 \mathrm{~F}$ (forward primer) was 5'AGAGTTTGATCMTGGCTCAG3' and universal bacterial primer 1492R (reverse primer) was 5'TACGGYTACCTTGTTACGACTT3' (Edwards et al., 1989).

\section{Culture medium and cultivation conditions}

Tyrosinase production was carried out in $250 \mathrm{~mL}$ flask contain $50 \mathrm{~mL} /$ flask of basal medium of Sharma et al. (2006) containing (g/L): casein, $10 ; \mathrm{K}_{2} \mathrm{HPO}_{4}, 0.5 ; \mathrm{MgSO}_{4} .7 \mathrm{H}_{2} \mathrm{O}, 0.25$; tyrosine, $10 ;(\mathrm{pH} 6.5)$, then sterilized by autoclaving at $121^{\circ} \mathrm{C}$. The inoculum was prepared by inoculating the flasks with a loop of the potent isolate and the flasks were then incubated on a rotary shaker at $200 \mathrm{rpm}$ and $37^{\circ} \mathrm{C}$ (Innova $4080 \mathrm{New}$ Brunswick Scientific CO., NJ, USA).

For the cultivation processes, the flasks were inoculated with $10 \%(\mathrm{v} / \mathrm{v})$ of the previously prepared vegetative cells. The effect of various carbon sources, such as C4-carbon sources (malic and succinic acids), C6-carbon sources (glucose, fructose, galactose, mannitol, and sorbose), C-12 carbon sources (maltose, sucrose, and lactose), and polysaccharides (starch, dextrin and cellulose) was investigated. Each carbon source was separately autoclaved and individually supplemented to the basal medium in a $10 \mathrm{~g} / \mathrm{L}$ concentration.

Various organic and inorganic nitrogen sources were individually supplemented in the basal medium as a substitute for casein in order to study their effect on tyrosinase production. The tested organic nitrogen sources (peptone, tryptone soybean, yeast extract, malt extract, and meat extracts) were added to the concentration of $10 \mathrm{~g} / \mathrm{L}$. On the other hand, the inorganic nitrogen sources under study $\left(\mathrm{NH}_{4} \mathrm{SO}_{4},\left(\mathrm{NH}_{4}\right) \mathrm{SO}_{4}, \mathrm{NaNO}_{3}, \mathrm{KNO}_{3}\right.$, and $\mathrm{NH}_{4} \mathrm{Cl}$ ) were added according to their nitrogen content to be equivalent to that of casein which was used as the control.

Concerning the effect of cultivation $\mathrm{pH}$ on growth and tyrosinase production, the broth medium was prepared in 250 $\mathrm{mL}$ Erlenmeyer flasks, and different $\mathrm{pH}$ values (5.0-10.0) were adjusted using $6 \mathrm{M} \mathrm{HCl}$ or $6 \mathrm{M} \mathrm{NaOH}$ and then autoclaved. At the end of each experiment, final $\mathrm{pH}$, bacterial growth, total protein content, and tyrosinase activity were determined.

\section{Determination of cell dry weight}

Cell dry weight was determined spectrophotometrically at $600 \mathrm{~nm}$ according to El-Enshasy and Elsyaed (2017). During cultivation, samples of cell growth were taken periodically and the O.D of the bacterial growth was measured after dilution to a range of $0-0.5$. Afterward, the sample was filtered using Whatman No. 1 filter paper, twice washed, dried overnight at $65^{\circ} \mathrm{C}$, and then weighed to get the final cell dry weight. A standard curve, drawn between the cell dry weight and the corresponding optical density, was used to derive the linear cell dry weight equation.

\section{Determination of total protein content}

Protein concentration was determined by the method of Lowry et al. (1951) using bovine serum albumin (BSA) as standard. 


\section{Determination of tyrosinase activity}

Tyrosinase activity is assayed by using L-tyrosine and L-DOPA as substrates. The appropriate concentration of the enzyme was assayed and an aliquot of the enzyme solution is added to a $0.1 \mathrm{M}$ sodium phosphate buffer ( $\mathrm{pH}$ 6.8) containing $1 \mathrm{mM}$ L-tyrosine and L-DOPA, and the formation of dopachrome is monitored by measuring the absorbance at $475 \mathrm{~nm}$. Dopachrome "colored intermediate" is an intermediate of melanin biosynthesis that is made from $O$-quinones by nonenzymatic oxidation. One international unit (IU) of tyrosinase activity is defined as the amount of enzyme required to oxidize $1 \mu \mathrm{mol}$ of L-tyrosine to dopachrome per minute under the above conditions (Danial et al. 2018).

\section{Statistical analysis}

All experiments performed were repeated for at least three times, and results were given as mean $\pm \mathrm{SD}$. Data were analyzed with the help of SPSS 9.0, and the mean comparison between different evaluated parameters was performed using ANOVA one-way analysis of variance. Statistical significance was defined when $p<0.05$.

\section{RESULTS AND DISCUSSION}

\section{Isolation, identification and molecular characterization of tyrosinase producing strain}

In this study, the $B$. subtilis possessing tyrosinase activity (250 U/min/mL in medium culture) was selected for enzyme production. According to the test, of $16 \mathrm{~S}$ rDNA (1434 bp) of the bacterial isolate was amplified and sequenced by Genetic Analysis Applied Biosystems. BLAST analysis showed 99\% identity of $B$. subtilis with $B$. subtilis DSM10. The phylogram was created using MEGA 7 software (Figure 1). Previously described criteria were used for this study: identification to the species level was defined as $>99 \%$ identity of the $16 \mathrm{~S}$ rRNA gene sequence with the sequence of its closest bacterial relative in the GenBank database, and identification at the genus level was defined as $>99 \%$ identity of the 16S rRNA gene sequence with the sequence of its closest bacterial relative in the GenBank database (Sambrook et al., 1989). This result was in good agreement with those obtained by Hullo et al. (2001) who isolated and studied tyrosinase from $B$. subtilis.

The obtained $16 \mathrm{~S}$ ribosomal ribonucleic acid (rRNA) sequence was compared with the National Center for Biotechnology Information (NCBI) Gen Bank database using the BLAST program. As a result, the isolated strain was confirmed to exhibit a very high homology with $B$. subtilis subs group (94\%) in its 16S rRNA nucleotide sequence (Figure 1). According to the obtained results, isolates were identified as B. subtilis strain (NA2).

\section{Optimization of cultivation conditions}

The optimization of different cultivation conditions was achieved by cultivating the isolated strain (B. subtilis NA2) in the basal cultivation medium, followed by evaluating tyrosinase production, cell dry weight, final $\mathrm{pH}$ and total protein content.

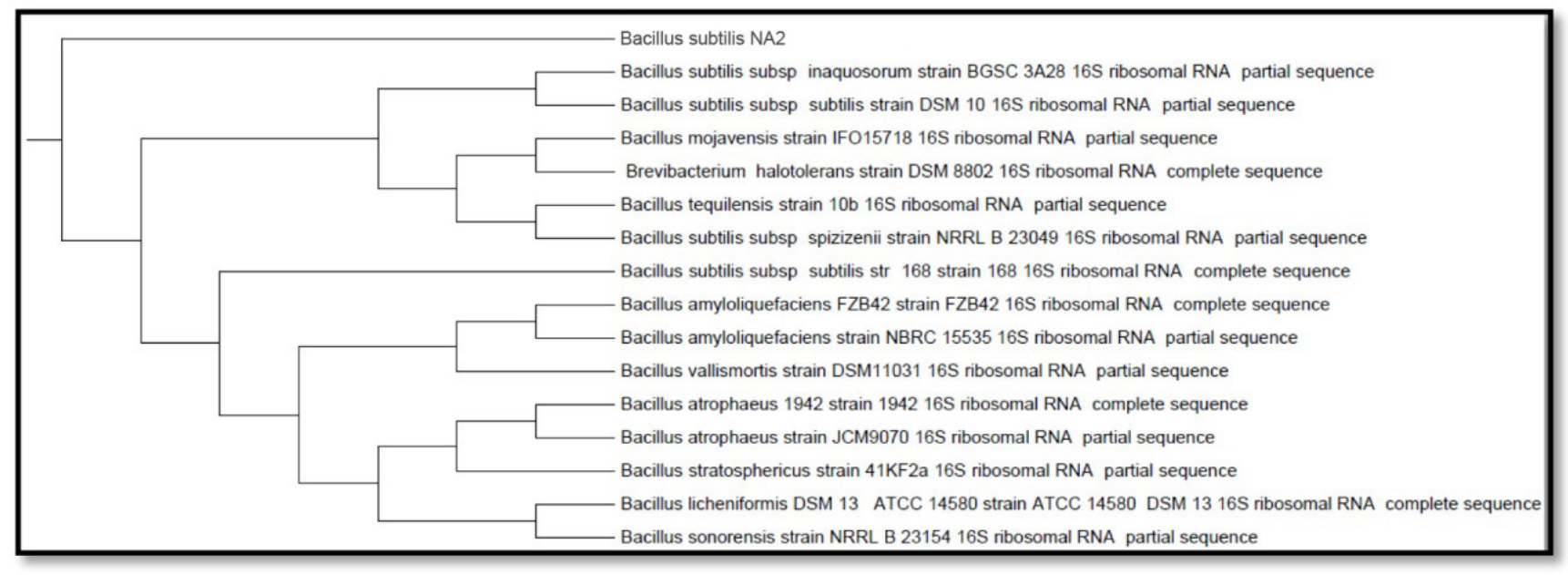

Fig. 1: Neighbor-joining phylogenetic representation of the strains and their closest relatives based on 16S rRNA gene sequences of $B$. subtilis NA2.

\section{Kinetics of cell growth and tyrosinase production}

The shake flasks containing the basal un-optimized cultivation medium were inoculated with the propagated cells and were then incubated as previously described. The obtained results (Figure 2) showed that cells grow exponentially with time with a cell growth rate of $0.1011 \mathrm{~g} / \mathrm{L} / \mathrm{h}$ and reached their maximal cell mass of $5.89 \mathrm{~g} / \mathrm{L}$ after $60 \mathrm{~h}$. After $60 \mathrm{~h}$, cell growth started to slow down and decreased by the end of the cultivation to reach $5.39 \mathrm{~g} / \mathrm{L}$. Accordingly, tyrosinase production increased with cell growth and reached a maximal of $416.67 \mathrm{U} / \mathrm{min} / \mathrm{mL}$ by $48 \mathrm{~h}$, after which tyrosinase production started to decrease and reached $246.67 \mathrm{U} / \mathrm{min} / \mathrm{mL}$ at $72 \mathrm{~h}$. During the exponential growth phase, tyrosinase was produced with an average production rate of $11.204 \mathrm{U} / \mathrm{mL} / \mathrm{h}$. Similarly, total protein content increased with time to reach a maximal of $844.8 \mathrm{mg} / \mathrm{mL}$ after $30 \mathrm{~h}$. The data for yield coefficients showed that the highest tyrosinase production yield $\left(Y_{P / X}\right)$ of $111.75 \times 10^{3} \mathrm{U} / \mathrm{g}$ cells was obtained after $36 \mathrm{~h}$ of cultivation. 


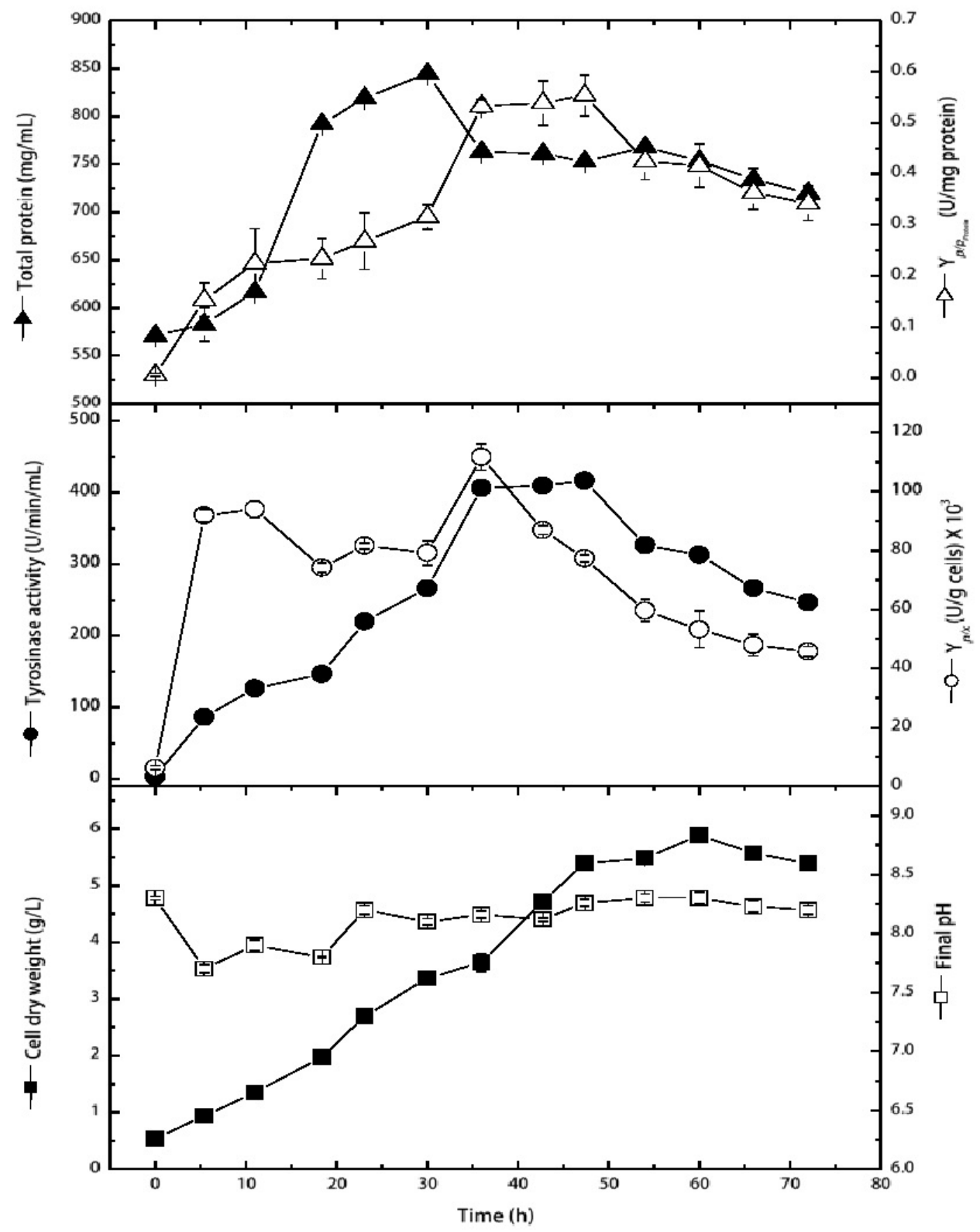

Fig. 2: Kinetics of cell growth and tyrosinase production by B. subtilis NA2.

The production of microbial enzymes depends mainly on the availability of suitable environmental conditions, i.e. physiological, nutritional and biochemical requirements. The obtained results can be correlated well with those obtained previously (Surwase et al., 2012a; Valipour and Arikan, 2016). The authors reported the same growth and production profiles for tyrosinase production by Brevundimonas sp. SGJ and $B$. megaterium M36, respectively. Moreover, they also reported a similar decline in the production of tyrosinase after reaching the maximal productivity at 18 and $16 \mathrm{~h}$ of cultivation and attributed such decline to the proteolytic degradation of the enzyme. Additionally, the decline in tyrosinase production after the stationary phase could be explained on the basis of the depletion of the available nutrients from the cultivation medium as well as the action of protease enzymes during decline phase
(Herwing et al., 2001; El-Enshasy and Elsyaed, 2017). Based on the aforementioned results the following optimization steps were performed, where the cultivation time was adjusted to $36 \mathrm{~h}$.

\section{Effect of different pH values on cell growth and tyrosinase production}

The cultivation medium was prepared in different sets with varying $\mathrm{pH}$ values. The tested $\mathrm{pH}$ ranged from 5.0 to 10.0 , and the flasks were then autoclaved, inoculated and incubated. After $36 \mathrm{~h}$, the cultivations were terminated and assayed for cell growth and tyrosinase production parameters. Results illustrated in Figure 3 revealed that the $\mathrm{pH}$ range from 5.5-8.0 did not largely affect cell growth, where the mean cell mass ranged from 6.24 $6.78 \mathrm{~g} / \mathrm{L}$. Furthermore, the highest cell mass of $7.60 \mathrm{~g} / \mathrm{L}$ was obtained at $\mathrm{pH}$ 9.0. On the other hand, increasing the initial $\mathrm{pH}$ 
of the cultivation medium greatly influenced the production of tyrosinase. Tyrosinase concentration increased gradually with increased initial $\mathrm{pH}$ and reached a maximal production of 453.33 $\mathrm{U} / \mathrm{min} / \mathrm{mL}$ at $\mathrm{pH}$ 8.5. Further increase in the initial $\mathrm{pH}$ resulted in a gradual decrease in the produced tyrosinase enzyme. Additionally, tyrosinase production yield coefficient based on cell mass $\left(Y_{P / X}\right)$ and produced protein $\left(Y_{P / \text { Protein }}\right)$ increased with increasing the initial $\mathrm{pH}$ value and reached their maximal yields of $62.42 \times 10^{3}$ $\mathrm{U} / \mathrm{g}$ cells and $0.55 \mathrm{U} / \mathrm{mg}$ protein, respectively.

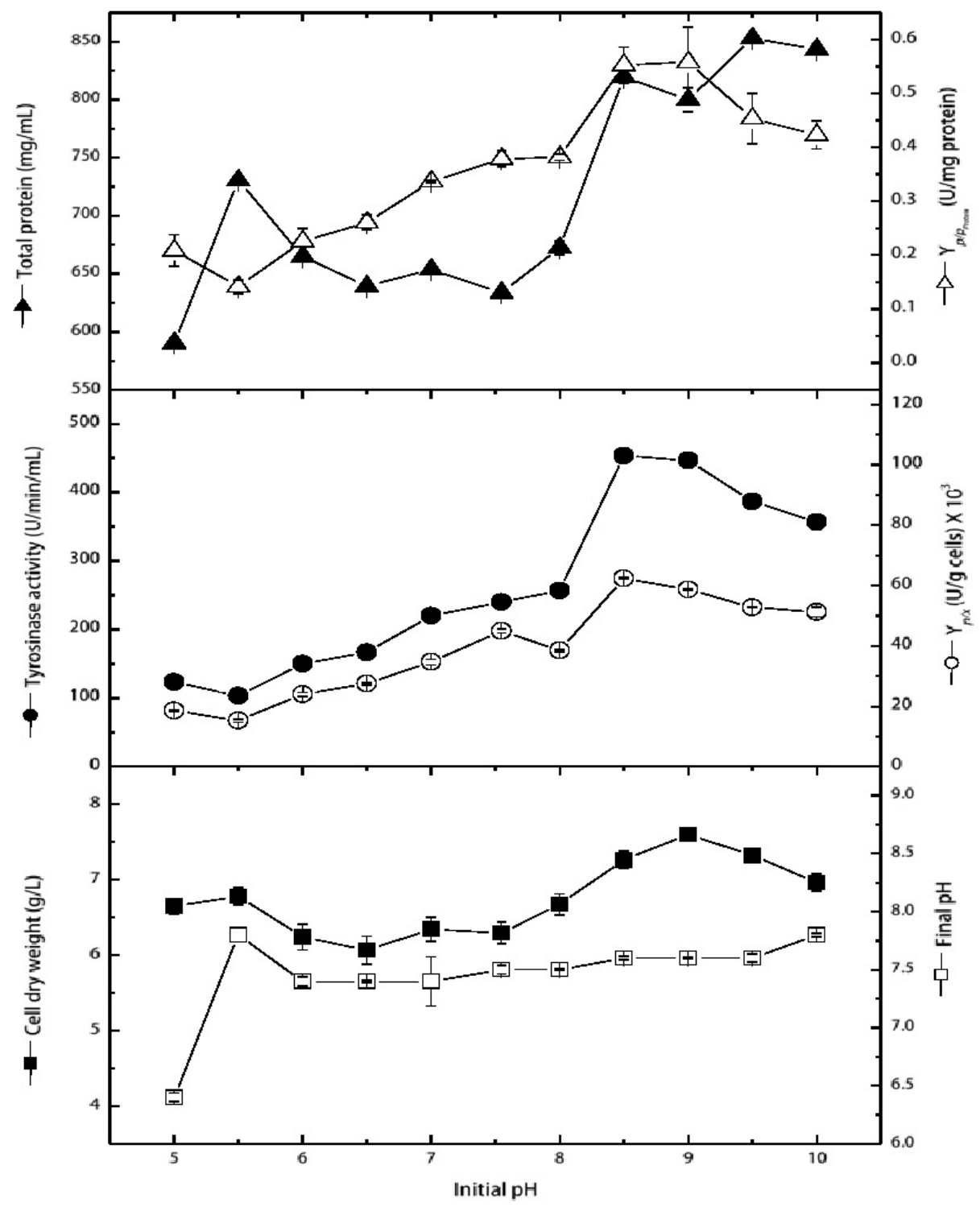

Fig. 3: Effect of different initial $\mathrm{pH}$ values on cell growth and tyrosinase production by $B$. subtilis NA2.

Generally, the producing microbe requires the $\mathrm{pH}$ of the cultivation medium to be set at the optimal and most favorable $\mathrm{pH}$ value. Suitable $\mathrm{pH}$ value is not only required for maximal growth, but also for higher enzyme productivity. This may be attributed to the fact that the transfer and uptake of nutrients and products across cell membranes is highly influenced by varying the concentration of hydrogen ions, which may lead to the alteration of spatial and structural geometries of various products (El-Enshasy and Elsayed, 2017). Accordingly, different microorganisms vary in their optimal $\mathrm{pH}$ values depending on their different biochemical and nutritional requirements. The obtained results are in good agreement with those of Rao et al. (2012), who found that $\mathrm{pH}$ range from 4.5 to 8.5 supported their tyrosinase production by an isolated RSP-T1 strain, with an optimal production $\mathrm{pH}$ of 6.5 . Moreover, Valipour and Arikan (2015) reported the same trend for their tyrosinase producing $B$. sp. MV29 strain and found that after $\mathrm{pH} 9.0$, the amount of the active enzyme declined significantly due to the change of the shape and configuration of the active site of the enzyme. Additionally, Surwase et al. (2012b) found that $\mathrm{pH}$ 8.0 was most optimal for the conversion of L-tyrosine to L-DOPA by the action of the tyrosinase produced from Brevundimonas sp. SGJ. Collectively, such results can be explained by the fact that $\mathrm{pH}$ response is a strain-dependent characteristic. Therefore, the initial $\mathrm{pH}$ of 8.5 was chosen for the following optimization steps. 


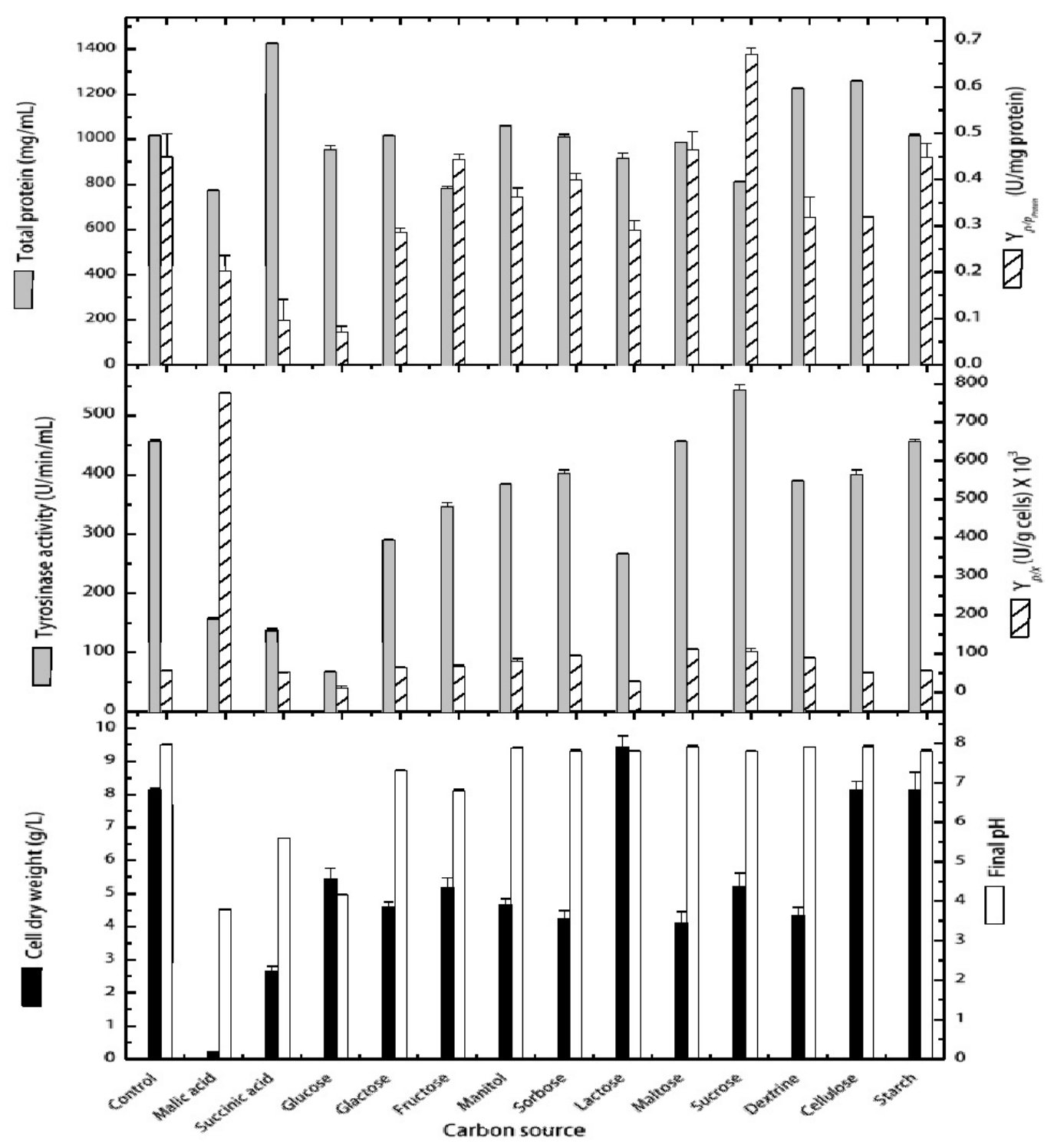

Fig. 4: Effect of different carbon sources on cell growth and tyrosinase production by B. subtilis NA2.

\section{Effect of different carbon sources on cell growth and tyrosinase production}

The cultivation medium was prepared to contain different carbon sources to evaluate their effect on cell growth and tyrosinase production. Tyrosine was added in $1 \%$ concentration as an inducer for the production of tyrosinase and was considered as the control cultivation medium. The other tested media contained $1 \%$ of the evaluated carbon sources. The obtained results (Figure 4) showed that the supplementation of the basal medium with either C4 or C6-carbon sources reduced both cell growth as well as tyrosinase production as compared to control cultivation medium containing only tyrosine. The addition of $1 \%$ malic acid or succinic acid reduced cell growth by about 97.5 and $67.6 \%$, and tyrosinase production by about 65.7 and $70.1 \%$, respectively. The addition of C6-carbon sources resulted in both moderate and variable cell growth and tyrosinase production; e.g. fructose produced 5.17 $\mathrm{g} / \mathrm{L}$ and $346.67 \mathrm{U} / \mathrm{min} / \mathrm{mL}$, while sorbose produced $4.25 \mathrm{~g} / \mathrm{L}$ and
403.33 U/min $/ \mathrm{mL}$, respectively. These values are lower than those obtained by the control cultivation, where tyrosine was added alone $(8.13 \mathrm{~g} / \mathrm{L}$ and $456.67 \mathrm{U} / \mathrm{min} / \mathrm{mL}$, respectively). The addition of C12-carbon sources showed that lactose greatly enhanced cell growth $(9.42 \mathrm{~g} / \mathrm{L})$, while tyrosinase production $(266.67 \mathrm{U} / \mathrm{min} / \mathrm{mL})$ was reduced by about $41.61 \%$ from control cultivation $(456.67$ $\mathrm{U} / \mathrm{min} / \mathrm{mL}$ ). Maltose addition reduced cell growth by about $50 \%$ $(4.11 \mathrm{~g} / \mathrm{L})$ but gave similar tyrosinase production $(456.67 \mathrm{U} / \mathrm{min} /$ $\mathrm{mL})$. On the other hand, sucrose was the most suitable carbon source added in terms of tyrosinase production $(543.33 \mathrm{U} / \mathrm{min} /$ $\mathrm{mL}$ ) which was $19 \%$ higher than the tyrosinase production obtained in control cultivation. In terms of cell dry weight, sucrose gave $5.21 \mathrm{~g} / \mathrm{L}$ cell dry weight, which was $36 \%$ lower than the cell dry weight obtained in the control cultivation. Polysaccharide addition enhanced both cell growth and tyrosinase production, but the production level remained lower or comparable to that of the control (dextrin, $390 \mathrm{U} / \mathrm{min} / \mathrm{mL}$; cellulose, $400 \mathrm{U} / \mathrm{min} / \mathrm{mL}$; starch, 
$456 \mathrm{U} / \mathrm{min} / \mathrm{mL}$ ). With the exception of malic acid, results of the tyrosinase production yield coefficient $\left(Y_{P / X}\right)$ showed that the yield coefficient was almost doubled when $1 \%$ sucrose was added to the cultivation medium in comparison to the control cultivation.

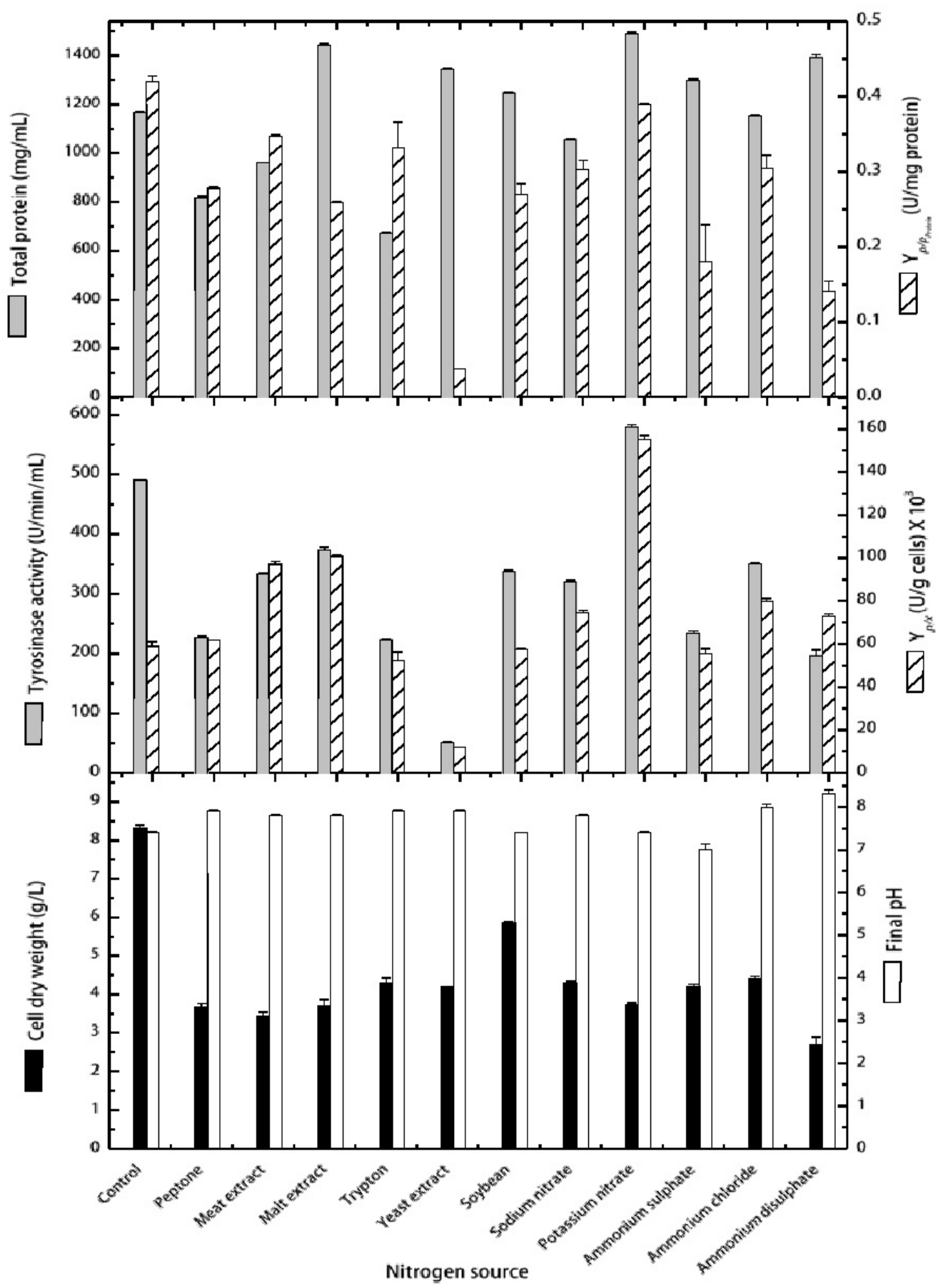

Fig. 5: Effect of different nitrogen sources on cell growth and tyrosinase production by B. subtilis NA2.

It can be generally seen that the isolated strain diverge greatly in its affinity towards different carbon sources. Carbon sources have been found to influence both cell growth as well as tyrosinase production depending on the producing strain. Valipour and Arikan (2015) reported that glucose, starch, and maltose increased tyrosinase yield by about 116.6 , 110 and $113 \%$, respectively. On the other hand, the yield was decreased to about 66.6 and 83.3 upon using glycerol and fructose, respectively. Morover, Chaskes et al. (2014) found that fructose was the best carbon source for tyrosinase production by Cryptococcus gattii, while Valipour and Arikan (2016) reported that glucose, starch, and other tested C-sources had no noticeable effect on the production of tyrosinase by $B$. megaterium M36. According to our obtained results, $1 \%$ sucrose was supplemented to the cultivation medium in the following optimization steps. 


\section{Effect of different nitrogen sources on cell growth and tyrosinase production}

Different organic and inorganic nitrogen sources were evaluated for their effect as casein substituents on cell growth and tyrosinase production. Different nitrogen sources were prepared to keep the $\mathrm{C}-\mathrm{N}$ ratio constant among all tested sources. The obtained results (Figure 5) showed that casein (control culture) and soybean nitrogen sources highly supported cell growth and biomass production, which gave highest cell growth values (8.31 and $5.85 \mathrm{~g} / \mathrm{L}$, respectively). In terms of tyrosinase production, results showed that potassium nitrate stimulated the highest tyrosinase production, where the maximal activity of $580 \mathrm{U} / \mathrm{min} / \mathrm{mL}$ was obtained. On the other hand, the control cultivation containing casein gave the second highest activity of $490.67 \mathrm{U} / \mathrm{min} / \mathrm{mL}$. However, yeast extract gave the lowest tyrosinase production (50 $\mathrm{U} / \mathrm{min} / \mathrm{mL}$ ). Generally, it can be noticed that, with the exception of potassium nitrate and casein, all other tested nitrogen sources gave decreased tyrosinase activities. Their obtained activities were lower by about $36-66 \%$ of the highest activity obtained. Furthermore, the highest production of tyrosinase obtained with potassium nitrate was reflected in the obtained yield coefficient. It can be seen that tyrosinase production yield coefficient $\left(Y_{P / X}\right)$ increased by about 2.6 folds upon using potassium nitrate instead of casein in the cultivation medium $58.96 \times 10^{3}$ and $155.2 \times 10^{3}$ $\mathrm{U} / \mathrm{g}$ cells for potassium nitrate and casein, respectively. This can be attributed either to the increased productivity of the strain or to the decreased cell biomass in case of potassium nitrate cultivation. The producing microorganisms vary distinctly in their behavior to different metabolic substrates. Various reports have mentioned that many tyrosinase producing strains use organic nitrogen sources, mainly tryptone and casein (Valipour and Arikan, 2015; 2016). They reported that tryptone followed by casein are the best nitrogen sources for tyrosinase production by their Bacillus sp. MV29 and B. megaterium M36 isolates. This can be explained by the fact that organic nitrogen sources provide the growing cells with all necessary vitamins and cofactors required for their metabolic activities. Furthermore, Valipour and Arikan (2015) noticed that using yeast extract above $0.1 \%$ in the production medium constantly decreased tyrosinase production. These observations are in good agreement with our results where yeast extract gave the lowest tyrosinase production. On the other hand, our results showed that potassium nitrate as an inorganic nitrogen source resulted in the highest tyrosinase activity among all tested nitrogen sources. These results are in accordance with Ingle and Khobragade (2013) who investigated the production of tyrosinase enzyme from three different soil bacterial isolates. Their results showed for all their three isolated strains, Rhodococcus ruber, Pseudomonas geniculata $\mathrm{C} 7$ and $P$. geniculata $\mathrm{C} 10$, that production of tyrosinase increased by about 2.5-2.7 folds for all strains upon using potassium nitrate as a nitrogen source instead of casein hydrolysate. Finally, Table 1 summarizes different cultivation parameters obtained from different optimization steps performed throughout the work.

Table 1. Growth and production parameters of tyrosinase production by Bacillus subtilis NA2 under different optimization steps.

\begin{tabular}{|c|c|c|c|c|}
\hline Parameter & Growth curve kinetics & Different $\mathrm{pH}^{* *}$ & Different C-source** & Different N-source** \\
\hline$X_{\max }[\mathrm{g} / \mathrm{L}]$ & $5.89^{*}$ & 7.26 & 5.21 & 3.74 \\
\hline$d X / d t\left[\mathrm{~g} / \mathrm{L} / \mathrm{h}^{-1}\right]$ & $0.18^{*}$ & n.d. & n.d. & n.d. \\
\hline$P_{\max }[\mathrm{U} / \mathrm{min} / \mathrm{mL}]$ & 416.67 & 453.33 & 543.33 & 580.00 \\
\hline$Q_{\mathrm{p}}[\mathrm{U} / \mathrm{mL} / \mathrm{h}]$ & $11.204^{*}$ & n.d. & n.d. & n.d. \\
\hline Total protein $_{\max }[\mathrm{mg} / \mathrm{mL}]$ & 844.8 & 819.4 & 811.2 & 1488.0 \\
\hline$Y_{P X X}[\mathrm{U} / \mathrm{g}$ cells $]$ & $111.75 \times 10^{3}$ & $62.41 \times 10^{3}$ & $104.27 \times 10^{3}$ & $155.19 \times 10^{3}$ \\
\hline$Y_{P / \text { Protein }}[\mathrm{U} / \mathrm{mg}$ produced protein $]$ & 0.554 & 0.553 & 0.670 & 0.390 \\
\hline
\end{tabular}

*Data were taken at the end of the exponential growth phase.

**Data taken at the end of the experiment for the optimized component. n.d.: not determined.

Abbreviations: $X_{\max }$, maximal cell dry weight; $d x / d t$, cell growth rate; $P_{\max }$, maximal volumetric tyrosinase production; $Q_{\mathrm{p}}$, average tyrosinase production rate; Total protein $_{\max }$, maximal total protein content; $Y_{P / X}, Y_{P / P \text { protein }}$, yield coefficients for g cells and mg produced protein, respectively.

\section{CONCLUSION}

The present work was designed to isolate and identify a newly tyrosinase producing strain. The most tyrosinase producing isolate was identified by $16 \mathrm{~S}$ rDNA technology as B. subtilis isolate and was designated NA2. Moreover, the isolated strain showed 99\% similarity with B. subtilis using BLAST analysis. Medium optimization experiments resulted in an increase of about $39.4 \%$ in volumetric tyrosinase production when compared with initial tyrosinase production obtained before the optimization of the medium composition. Furthermore, the specific activity of tyrosinase production (U/g cells) was also improved by about $39.6 \%$ upon the optimization. This improvement is mainly due to increased cell productivity and not due to microbial cell mass.

\section{REFERENCES}

Allouche N, Damak A, Ellouz R, Sayadi S. Use of whole cells of Pseudomonas aeruginosa for synthesis of the antioxidant hydroxytyrosol via conversion of tyrosol. Appl Environ Microbiol, 2004; 70(4):2105-2109.

Caf Y, Maaşoğlu Y, Valipour E, Arikan B. Production and characterization of novel cold-active, $\mathrm{pH}$ tolerant and detergent-stable: $\alpha$-amylase from a psychrotrophic bacterium from soil samples. New Biotechnol, 2012; 29:S82.

Chaskes S, Cammer M, Nieves E, Casadevall A. Pigment production on L-tryptophan Medium by Cryptococcus gattii and Cryptococcus neoformans. PLoS One, 2014; 9(4):e91091.

Claus H, Decker H. Bacterial tyrosinases. Syst Appl Microbiol, 2006; 29(1):3-14.

Dalfard AB, Khajeh K, Soudi MR, Naderi-Manesh H, Ranjbar $\mathrm{B}$ and Sajedi RH. Isolation and biochemical characterization of laccase and 
tyrosinase activities in a novel melanogenic soil bacterium. Enzyme Microb Technol, 2006; 39(7):1409-1416.

Danial NE, Al-Bishri WM. Optimization of medium composition for increased production of tyrosinase enzyme in recombinant Bacillus megaterium. Res J Pharm Biol Chem Sci, 2018; 9(1):480-486.

Decker H, Tuczek F. Tyrosinase/catecholoxidase activity of hemocyanins: structural basis and molecular mechanism. Trends Biochem Sci, 2000; 25(8):392-397.

Edwards U, Rogall T, Blocker H, Emde M, Bottger EC. Isolation and direct complete nucleotide determination of entire genes. Nucleic Acids Res, 1989; 17:7843-7853.

El-Enshasy HA, Elsayed EA. Kinetics of cell growth and invertase production by the biotherapeutic yeast, Saccharomyces boulardii. J Sci Ind Res, 2017; 76(8):477-484.

Franciscon E, Grossman MJ, Paschoal JA, Reyes FG, Durrant LR. Decolorization and biodegradation of reactive sulfonated azo dyes by a newly isolated Brevibacterium sp. strain VN-15. Springer Plus, 2012; $1(1): 37$.

Herwig C, Doerries C, Marison I, Stockar U, Quantitative analysis of the regulation scheme of invertase expression in Saccharomyces cerevisiae. Biotechnol Bioeng, 2001; 76:247-258.

Hullo MF, Moszer I, Danchin A, Martin-Verstraete I. CotA of Bacillus subtilis is a copper-dependent laccase. J Bacteriol, 2001; 183:54265430.

Ingle SS, Khobragade CN, Production and purification of the tyrosinase enzyme from soil bacteria. Helix, 2013; 6:436-440.

Kumar CG, Mongolla P, Pombala S, Kamle A, Joseph J. Physicochemical characterization and antioxidant activity of melanin from a novel strain of Aspergillus bridgeri ICTF-201. Lett Appl Microbiol, 2011; 53 (3):350-358.

Lowry OH, Rosebrough NJ, Farr AL, Randal RJ. Protein measurement with the Folin phenol reagent. J Biol Chem, 1951; 193:265275

Marino SM, Fogal S, Bisaglia M, Moro S, Scartabelli G, De Gioia L, Spada A, Monzani E, Casella L, Mammi S, Bubacco L. Investigation of Streptomyces antibioticus tyrosinase reactivity toward chlorophenols. Arch Biochem Biophys, 2011; 505(1):67-67.

Pandey G, Muralikrishna C, Bhalerao UT. Mushroom tyrosinase catalyzed synthesis of coumestans, benzofuran derivatives and related heterocyclic-compounds. Tetrahedron, 1989; 45(21):6867-6874.

Rao SKRS, Tripathy NK, Mahalaxmi Y, Prakasham RS. Laccase- and peroxidase-free tyrosinase production by isolated microbial strain. J Microbiol Biotchnol, 2012; 22(2):207-214.
Rao SKRS, Tripathy NK, Rao SD, Prakasham RS. Production, characterization, catalytic and inhibitory activities of tyrosinase. Res J Biotechnol, 2013; 8(1):87-99.

Sambrook J, Fritsch EF, Maniatis T. Molecular cloning A. Laboratory Manual. Cold Spring Harbor Laboratory, NY. 1989.

Saratale RG, Saratale GD, Chang JS, Govindwar SP. Bacterials decolorization and degradation of azo dyes: A review. J Taiwan Inst Chem Eng, 2011; 42(1):138-157.

Sharma AD, Kainth S, Gill PK. Inulinase production using garlic (Allium sativum) powder as a potential substrate in Streptomyces sp. J Food Eng, 2006; 77:486-491.

Seo SY, Sharma VK, Sharma N. Mushroom tyrosinase: Recent prospects. J Agric Food Chem, 2003; 51(10):2837-2853

Shuster V, Fishman A. Isolation, cloning and characterization of a tyrosinase with improved activity in organic solvents from Bacillus megaterium. J Mol Microbiol Biotechnol, 2009; 17(4):188-200.

Surwase SN, Patil SA, Apine OA, Jadhav JP. Efficient microbial conversion of L-tyrosine to L-DOPA by Brevundimonas sp. SGJ. Appl Biochem Biotechnol, 2012b; 167:1015-1028.

Surwase SN, Patil SA, Jadhav SB, Jadhav JP. Optimization of 1-DOPA production by Brevundimonas sp. SGJ using response surface methodology. Microb Biotechnol, 2012a; 5(6):731-737.

Valipour E, Arikan B. Optimization of tyrosinase enzyme production from native Bacillus sp. MV29 isolate. J Appl Biol Sci, 2015; 9(2):77-82

Valipour E, Arikan B. Increased production of tyrosinase from Bacillus megaterium strain M36 by the response surface methods. Arch Biol Sci, 2016; 68(3):659-668.

$\mathrm{Xu} \mathrm{DY}$, Chen JY, Yang Z. Use of cross-linked tyrosinase aggregates as catalyst for synthesis of L-DOPA. Biochem Eng J, 2012; 63:88-94.

Zhang T, Wen S, Tan T. Optimization of the medium for glutathione production in Saccharomyces cerevisiae. Process Biochem, 2007; 42:454-458.

\section{How to cite this article:}

Elsayed EA, Danial EN. Isolation, Identification and Medium Optimization for Tyrosinase Production by a Newly Isolated Bacillus subtilis NA2 Strain. J App Pharm Sci, 2018; 8(09): 093101. 